\title{
Kepastian Nilai Dasar Penghitungan Bea Perolehan Hak Atas Tanah dan Bangunan (BPHTB)*
}

\author{
R. Murjiyanto dan Samun Ismaya \\ Fakultas Hukum Universitas Janabadra \\ Jl. Timoho II/40 Yogyakarta \\ rmurjiya@yahoo.com; samunismaya@gmail.com
}

\begin{abstract}
The problems in this research are formulated as follow, first, how is the standard value calculated in the transition of BPHTB land rights? Second, how to assure the standard value in the calculation of BPHTB on the transfer of land rights? This research is a normative research supported by empirical data with the approach of legislations. On the basis of this study we concluded that, first, there is uncertain quantification of BPHTB amount to be paid, with the obligation that inhibit the validation process of registration of land rights transfer. Secondly, there should be standard fixed value as the basis for calculating BPHTB by the competent authority, such as the Taxable Value on Property Tax.
\end{abstract}

Keyword : Standard value calculation of BPHTB.

\section{Abstrak}

Permasalahan dalam penelitian ini yaitu, pertama, bagaimanakah kepastian nilai perhitungan BPHTB dalam peralihan hak atas tanah? Kedua, bagaimana agar terdapat kepastian dalam perhitungan BPHTB atas peralihan hak atas tanah? Penelitian ini merupakan penelitian normatif yang didukung dengan data empiris, dengan pendekatan perundang-undang. Dari penelitian ini diperoleh kesimpulan, pertama terjadi ketidakpastian penghitungan dan jumlah BPHTB yang harus dibayar, dengan kewajiban validasi yang menghambat proses pendaftaran peralihan hak atas tanah. Kedua, perlu ditetapkan nilai sebagai dasar perhitungan BPHTB oleh instansi yang berwenang, seperti Nilai Jual Obyek Pajak pada Pajak Bumi dan Bangunan.

Kata Kunci : Kepastian Nilai Perhitungan BPHTB.

* Makalah Hasil Penelitian Hibah Bersaing yang Didanai Oleh Direktorat Jenderal Pendidikan Tinggi Kementerian Pendidikan dan Kebudayaan RI Tahun 2014. 


\section{Pendahuluan}

Dalam pelaksanaan pemungutan dan atau pembayaran Bea Perolehan Hak atas Tanah dan Bangunan (BPHTB) baik sejak berlakunya Undang-Undang No. 21 Tahun 1997 tentang Bea Perolehan Hak Atas Tanah dan Bangunan, yang telah dirubah dengan Undang-Undang Nomor 20 Tahun 2000 tentang Perubahan Undang-Undang No. 21 Tahun 1997 tentang Bea Perolehan Hak Atas Tanah dan Bangunan yang kemudian disebut UU BPHTB semula merupakan pajak pusat, maupun dengan berlakunya Undang-Undang Nomor 28 Tahun 2009 tentang Pajak Daerah dan Retribusi Daerah (UU PDRD), yang kemudian menjadi pajak daerah masih menimbulkan permasalahan bagi masyarakat yang melakukan perbuatan hukum peralihan hak atas tanah, seperti jual beli, hibah ataupun warisan, yang seringkali tidak paham dengan ketentuan dalam hal cara pemungutan dan cara penentuan besarnya BPHTB yang harus mereka bayarkan. Pelimpahan pajak pusat menjadi pajak daerah ini sesuai dengan sistem desentralisasi yang memiliki dua tingkatan, yaitu pemerintah pusat dan pemerintah daerah ${ }^{1}$, yang masing-masing tingkat pemerintahan memiliki kewenangan melakukan pemungutan pajak. Dalam melaksanakan kewenangan pemungutan BPHTB menjadi pajak daerah tersebut dibuat peraturan daerah atas persetujuan DPRD, karena menyangkut hak, kewajiban, dan kekayaan rakyat daerah. ${ }^{2}$

Salah satu hal yang menimbulkan permasalahan adalah penggunaan nilai transaksi yang digunakan sebagai dasar perhitungan BPHTB. Ketentuan tentang dasar yang digunakan sebagai dasar perhitungan BPHTB baik yang diatur dalam UU BPHTB maupun dalam UU PDRD adalah dengan menggunakan nilai transaksi.Nilai transaksi adalah nilai yang merupakan kesepakatan antara para pihak yang melakukan transaksi, seperti kalau dalam jual beli, adalah antara penjual dengan pembeli.Sehingga kepastian hukum nilai transaksi turut dalam menentukan sah tidaknya sebuah jual beli, dalam hal ini apakah benar bahwa nilai transaksi baik yang dicantumkan dalam akta jual beli maupun yang digunakan sebagai dasar

${ }^{1}$ Adrian Sutedi, Hukum Pajak dan Retribusi Daerah, Ghalia Indonesia, Bogor, 2008, hlm. 13

${ }^{2}$ Murtir Jeddawi, Implementasi Kebijakan Otonomi Daerah (Analisis Kewenangan, Kelembagaan, managemen Kepegawaian, dan Peraturan Daerah), Total Media, Yogyakarta, 2008, hlm. 39. 
perhitungan BPHTB adalah benar-benar sesuai dengan kenyataan yang telah disetujui atau disepakati oleh pihak-pihak yang melakukan transaksi.

Adanya penggunaan nilai transaksi sebagai dasar perhitungan ВРНТВ inilah yang sering kali menimbulkan permasalahan di lapangan, karena tidak jarang nilai transaksi yang diajukan oleh wajib pajak dianggap tidak sesuai oleh petugas pajak, sehingga tidak jarang petugas pajak dalam proses verifikasi/ validasi, meminta agar nilai transaksi diubah dan disesuaikan menurut penilaian petugas pajak. Hal ini dapat terjadi karena merupakan suatu hal yang wajar, bahwa pada umumnya orang berkeinginan agar membayar pajaknya ringan, sehingga nilai yang dicantumkan dalam akta dan yang digunakan sebagai dasar perhitungan BPHTB tidak sesuai dengan kenyataan yang sebenarnya yang telah disetujui oleh pihak-pihak.

Demikian juga sebaliknya, petugas pajak menginginkan pajak yang dibayar dapat maksimal. Penggunaan nilai transaksi sesuai dengan harga pasar cenderung jauh lebih tinggi dari Nilai Jual Obyek Pajak Bumi dan Bangungan (NJOP PBB), sehingga petugas pajak dalam menentukan nilai transaksi yang sebenarnya tidaklah mudah, dalam melakukan penelitian atas kebenaran nilai transaksi yang dipakai wajib pajak untuk menghitung BРHTB, petugas dinas harus mencari data dan keterangan ataupun informasi dari berbagai pihak, yang sebenarnya tidak mudah untuk memperoleh nilai yang pasti dan menjamin kebenaran. Bahkan tidak menutup kemungkinan nilai transaksi yang ditentukan oleh petugas pajak ini justru tidak sesuai dengan kenyataan yang sebenarnya, hal inilah yang menjadi masalah karena tidak adanya kepastian mengenai nilai transaksi. Pada dasarnya nilai transaksi dalam sebuah jual beli ditentukan semata oleh para pihak sendiri berdasarkan kesepakatan, dan tidak ada satu pihak manapun yang dapat menentukan, apalagi memaksa untuk menggunakan nilai tertentu.Dalam hal terjadi pemaksaan dan/ atau suatu tindakan yang mengakibatkan nilai transaksi tidak sesuai dengan kenyataan yang telah disepakati oleh pihak-pihak, maka transaksinya dapat menjadi tidak sah dan batal.

Dari gambaran tersebut, maka nilai transaksi baik yang diajukan oleh wajib pajak yang dimuat dalam akta dan sebagai dasar perhitungan BPHTB dengan nilai transaksi menurut penilaian petugas pajak dalam proses validasi adalah bersifat 
relatif dan subyektif, sehingga dapat menimbulkan ketidakpastian. Ketidakpastian ini dapat menimbulkan berbagai konsekuensi hukum, antara lain, dapat mengakibatkan transaksinya menjadi tidak sah dan menjadi batal, bahkan dapat merugikan masyarakat, karena harus membayar pajak yang lebih tinggi dari yang seharusnya. Di samping itu, juga menimbulkan prosedur yang rumit dan panjang, karena diperlukan proses validasi yang kadang memakan waktu yang rumit dan lama. Berdasarkan hal tersebut, maka perlu dikaji secara mendalam mengenai nilai yang tepat dan pasti sebagai dasar penghitungan pengenaan BPHTB yang harus dibayar oleh masyarakat yang melakukan peralihan hak atas tanah.

\section{Rumusan Masalah}

Berdasarkan uraian dalam latar belakang tersebut, maka penelitian ini didasarkan atas permasalahan sebagai berikut: Pertama, bagaimanakah kepastian nilai yang digunakan dalam perhitungan pembayaran BPHTB dalam peralihan hak atas tanah? Kedua, bagaimana agar terdapat kepastian nilai yang digunakan dalam perhitungan BPHTB atas peralihan hak atas tanah?

\section{Tujuan Penelitian}

Adapun tujuan dalam penelitian ini, adalah: pertama, untuk mengetahui pengaruh penggunaan nilai transaksi sebagai dasar penghutungan ВРНTB terhadap kepastian perhitungan dan jumlah BPHTB yang harus dibayar. Kedua, untuk menentukan pilihan nilai yang digunakan sebagai dasar perhitungan BPHTB, agar diperoleh kepastian dalam perhitungan dan pembayaran BPHT.

\section{Metode Penelitian}

Penelitian ini merupakan penelitian normatif (legal research) ${ }^{3}$ atau disebut juga dengan penelitian doktrinal ${ }^{4}$, yang didukung dengan data empiris. Metode pendekatan yang digunakan yaitu pendekatan perundang-undangan, yang 
dikombinasikan dengan data empiris di lapangan baik dari responden maupun narasumber. Responden terdiri dari unsur masyarakat dan PPAT serta didukung dari sejumlah narasumber. Adapun lokasi penelitian yaitu di wilayah Kantor Dinas Pendapatan Daerah Kabupaten / Kota yang mengelola BPHTB, dan Pejabat Kantor Pertanahan (BPN) di tiga wilayah Daerah Istimewa Yogyakarta, meliputi daerah Kabupaten Bantul, Kabupaten Sleman, dan Kota Yogyakarta.

Data dan keterangan yang diperoleh dari lapangan, baik melalui penggunaan daftar pertanyaan dan wawancara kepada responden maupun narasumber, maupun dari studi kepustakaan kemudian direduksi dengan mendasarkan pada upaya untuk menjawab permasalahan dan tujuan penelitian yang diajukan. Data yang sudah direduksi sesuai dengan pokok masalah dan didukung dengan peraturan perundang-undangan yang berlaku selanjutnya direkonstruksi dengan pendekatan kualitatif ke dalam uraian deskriptif kualitatif dan akhirnya diambil kesimpulan.

\section{Hasil Penelitian dan Pembahasan}

\section{Nilai yang Digunakan dalam Perhitungan BPHTB}

Bea Perolehan Hak atas Tanah dan Bangunan dikenakan bagi pihak baik perseorangan maupun badan hukum yang memperoleh hak atas tanah dan bangunan. Seseorang atau badan hukum dapat memperoleh hak atas tanah dan bangunan dapat berasal dari beberapa sebab, antara lain karena jual beli, hibah, warisan, tukar menukar dan lain-lain. Jual-beli sebagai salah satu sebab seseorang memperoleh hak atas tanah dan bangunan pada hakekatnya sebagai perbuatan pengalihan hak kepada pihak/orang lain dari penjual kepada pembeli. ${ }^{5}$ Dengan memperoleh hak atas tanah dan bangunan maka pihak yang memperoleh hak tersebut dikenakan pajak yang disebut Bea Perolehan Hak Atas Tanah dan Bangunan atau BРHTB, baik diperoleh karena jual beli, hibah, hibah wasiat atau warisan, tukar menukar atau perolehan lainnya yang menjadi obyek BPHTB sesuai dengan ketentuan undang-undang.

${ }^{5}$ Harun Al Rashid, Sekilas tentang Jual Beli Tanah (Berikut Peraturan-peraturannya), Ghalia Indonesia, Jakarta, 1987, hlm. 50 . 
Pasal 1 Undang-Undang Nomor 28 Tahun 2009 tentang Pajak Daerah dan Retribusi Daerah maupun Pasal 1 Undang-undang Nomor 21 Tahun 1997 tentang Bea Perolehan Hak atas Tanah dan Bangunan sebagaimana telah diubah dengan UU Nomor 20 Tahun 2000 tentang Perubahan Undang-Undang No. 21 Tahun 1997 tentang Bea Perolehan Hak Atas Tanah dan Bangunan menjelaskan bahwa: "Perolehan Hak atas Tanah dan/atau Bangunan adalah perbuatan atau peristiwa hukum yang mengakibatkan diperolehnya hak atas tanah dan atau bangunan oleh orang pribadi atau badan". Sedangkan menurut kedua undang-undang tersebut, yang dimaksud dengan Bea Perolehan Hak atas Tanah dan Bangunan atau BPHTB adalah pajak atas perolehan hak atas tanah dan/atau bangunan.Perolehan hak karena perbuatan hukum adalah perolehan hak yang disebabkan karena perbuatan hukum peralihan hak, seperti jual beli, tukar menukar, hibah, pemasukan dalam perusahaan dan perbuatan hukum pemindahan hak lainnya.Sedangkan perolehan hak karena peristiwa hukum adalah perolehan hak terjadi karena hukum, yang disebabkan karena suatu peristiwa hukum tertentu, seperti meninggalnya pemegang hak, maka ahli waris yang berhak memperoleh hak karena hukum, tanpa ada perbuatan hukum tertentu. ${ }^{6}$

Dalam penjelasan lain, bahwa Perolehan Hak atas Tanah dan/atau Bangunan adalah perbuatan atau peristiwa hukum yang mengakibatkan diperolehnya hak atas tanah dan/atau bangunan oleh orang pribadi atau Badan. Sedangkan yang dimaksud dengan Bea Perolehan Hak atas Tanah dan Bangunan atau BPHTB adalah pajak atas perolehan hak atas tanah dan/atau bangunan. ${ }^{7}$

Subjek BPHTB adalah orang pribadi atau badan yang memperoleh hak atas tanah dan bangunan. Subjek pajak yang dikenakan kewajiban membayar pajak menjadi Wajib Pajak (WP) BPHTB.Sebagaimana di Indonesia dikenal subjek hak dapat dimiliki oleh orang pribadi maupun badan hukum. Orang pribadi adalah manusia sebagai orang perseorangan yang dapat memperoleh suatu hak seperti hak atas tanah, sedangkan badan hukum adalah segala sesuatu yang dapat mempunyai hak dan kewajiban, dapat melakukan perbuatan hukum, dapat menjadi subjek

6Boedi Harsono. Hukum Agraria Indonesia, Djambatan, Jakarta, 2007, hlm. 519

7 Lihat Undang-Undang Nomor 28 Tahun 2009 tentang Pajak Daerah dan Retribusi Daerah (Tambahan Lembaran Negara Republik Indonesia Nomor 5049) 
hukum, memiliki harta kekayaan dan tanggungjawab sendiri yang terpisah dari orang perseorangan.

Menurut Pasal 85 Undang-Undang Nomor 28 Tahun 2009 tentang Pajak Daerah dan Retribusi Daerah atau UU PDRD, objek BPHTB adalah perolehan hak atas tanah dan atau bangunan. Hal tersebut sama seperti yang dijelaskan pada Pasal 2 Undang-undang Nomor 21 Tahun 1997 tentang Bea Perolehan Hak atas Tanah dan Bangunan sebagaimana telah diubah dengan UU Nomor 20 Tahun 2000 tentang Perubahan Undang-Undang No. 21 Tahun 1997 tentang Bea Perolehan Hak Atas Tanah dan Bangunan atau UU BPHTB. Perolehan hak atas tanah dan atau bangunan meliputi antara lain, karena pemindahan hak berupa Jual beli, Tukar menukar, Hibah, Hibah wasiat, Waris, Pemasukan dalam perseroan atau badan hukum lain, lelang, Pelaksanaan putusan hakim yang mempunyai kekuatan hukum tetap, atau Penggabungan Perusahaan.

Berlakunya UU PDRD, maka pengelolaan BPHTB yang semula menjadi pajak pusat dan dikelola oleh pemerintah pusat melalui Direktorat Jenderal Pajak dalam lingkungan Kementerian Keuangan, beralih menjadi pajak daerah dan dikelola oleh pemerintah daerah kabupaten/ kota melalui dinas pendapatan.

Sistem pemungutan pajak secara umum di Indonesia, menganut sistem self assessment yaitu wajib pajak diberikan kepercayaan untuk dapat menghitung, memperhitungkan, dan membayar sendiri pajak yang terutang, sehingga melalui sistem ini pelaksanaan administrasi perpajakan diharapkan dapat dilaksanakan dengan rapi, terkendali, sederhana, dan mudah untuk dipahami oleh anggota masyarakat wajib pajak. ${ }^{8}$ Ciri-ciri Self Assessment System adalah: a. wewenang untuk menentukan besarnya pajak terhutang ada pada wajib pajak sendiri; $b$. wajib pajak aktif, mulai dari menghitung, menyetor dan melaporkan sendiri pajak yang terhutang; c. fiscus tidak ikut campur dan hanya mengawasi. ${ }^{9}$

Kecuali terhadap pajak-pajak tertentu, seperti Pajak Bumi dan Bangunan, perhitungannya ditetapkan oleh pemerintah. Sedang dalam pemungutan BPHTB pada dasarnya juga didasarkan sistem self assessment, sehingga pihak yang memperoleh hak atas tanah dan bangunan sebagai wajib pajak harus

\footnotetext{
8 Padmo Wahjono, Undang-undang Perpajakan Beserta Penjelasan dan Peraturan Pelaksanaan, Ghalia Indonesia, Jakarta, 1984, hlm. 51.

${ }_{9}^{9}$ Y. Sri Pudiatmoko, Pengantar Hukum Pajak, Penerbit Andi, Yogyakarta, 2002, hlm. 61.
} 
menghitung, memperhitungkan, dan membayar sendiri pajaknya. Dengan demikian diperlukan adanya kesadaran dan kejujuran yang tinggi bagi masyarakat wajib pajak untuk melaksanakan kewajibannya dalam membayar pajak, dan diperlukan peran dari petugas pajak dalam melakukan pengawasan terhadap kepatuhan wajib pajak dalam membayar pajak, demikian pula dalam penerimaan dan pengelolaannya.

Dalam rangka pengawasan terhadap kepatuhan wajib pajak, sekaligus efektifitas dalam membayar pajak BPHTB dilakukan proses validasi oleh kantor pelayanan pajak daerah, yang semula juga dilakukan oleh kantor pelayanan pajak pusat melalui Kantor Pelayanan Pajak Pratama (KPP Pratama). Dalam proses validasi inilah petugas akan meneliti beberapa hal di antaranya tentang kesesuaian obyek pajak dengan Nomor Obyek Pajak (NOP) atas tanah dan bangunan yang bersangkutan, kesesuaian antara subyek pajaknya, kesesuaian nilai transaksi yang digunakan sebagai dasar pengenaan pajak BPHTB. Dengan demikian dalam sistem pemungutan BPHTB tidak sepenuhnya menganut sistem self assessment, dalam hal ini sekalipun wajib pajak diberi kepercayaan untuk dapat menghitung, memperhitungkan, dan membayar sendiri pajak yang terutang, ada kemungkinan campur tangan petugas pajak dalam menentukan nilai kewajaran. Dalam proses validasi tersebut apabila ada keraguan dari petugas pajak terhadap nilai transaksi yang digunakan sebagai dasar pengenaan BPHTB, ada kemungkinan dilakukan penelitian secara cermat, bila diperlukan diadakan peninjauan lokasi oleh petugas lapangan dengan mencari informasi nilai umum secara wajar dengan memperbandingkan NJOP atas tanah dan bangunan yang bersangkutan. Sehingga berdasarkan hasil validasi ada kemungkinan nilai yang diajukan sebagai dasar pengenaan BPHTB dilakukan perubahan sesuai dengan nilai transaksi yang sebenarnya secara wajar.

Sebagaimana diatur dalam Pasal 87 UU PDRD, bahwa yang menjadi dasar pengenaan Bea Perolehan Hak atas Tanah dan Bangunan adalah Nilai Perolehan Objek Pajak. Sedangkan yang dimaksud dengan Nilai Perolehan Objek Pajak sebagaimana dimaksud adalah nilai transaksi untuk peralihan karena jual beli atau nilai pasar untuk peralihan lainnya. Penggunaan nilai transaksi atau nilai pasar inilah yang menimbulkan ketidakpastian, karena nilai transaksi atau nilai pasar terhadap 
sebuah obyek itu bagi beberapa pihak sifatnya relatif, tergantung nilai itu bagi siapa, apakah bagi pihak-pihak, bagi petugas pajak, atau lainnya, sehingga sulit akan diperoleh nilai yang sama dan pasti. Sedangkan legalitas sebuah transaksi diperlukan adanya kebenaran dan kepastian hukum termasuk menyangkut nilai transaksi.

Adapun tarif pengenaan BPHTB bagi pembeli atau yang memperoleh hak terhadap semua transaksi peralihan tanah adalah sebesar $5 \%$. Dengan perhitungan : Nilai Perolehan dikurangi Nilai Perolehan Tidak Kena Pajak (NPTKP) untuk wilayah Kabupaten/ Kota DIY sebesar Rp. 60.000.000,- kali tarif 5\%. Sebagai contoh sebuah transaksi dengan nilai perolehan sebesar Rp. 200.000.000,-. BPHTB yang harus dibayar adalah $=$ Rp. 200.000.000,- - Rp. 60.000.000,- = Rp. 140.000.000,- x 5\% = Rp 7.000.000,-. Di samping itu, bagi penjual atau pihak yang mengalihkan dikenakan Pajak Penghasilan atas penjualan tanah dan bangunan dengan tarif sebesar 5\%, sehingga dengan nilai perolehan Rp. 200.000.000,- maka penjual akan dikenakan PPh sebesar $=200.000 .000,-$ x 5\% = Rp. 10.000.000,-.

Berdasarkan data dan keterangan yang diperoleh dalam pelaksanaan jual beli, pada umumnya pihak-pihak penjual dan pembeli akan datang ke kantor PPAT Notaris yang sudah dikenal atau dalam memilih PPAT Notaris kalau tidak sudah dikenal, setidaknya berdasarkan informasi dari orang yang sudah dipercaya. Hal ini berkaitan dengan unsur kepercayaan antara para pihak dengan PPAT notaris yang bersangkutan, karena dengan PPAT Notaris yang sudah dikenal tentu akan lebih memberikan jaminan keamanan dan ketenangan bagi para pihak, dalam arti kelancaran proses dalam peralihan jual beli sampai dengan pendaftarannya ke Kantor Pertanahan, bahkan termasuk dalam hal pembayaran pajak yang berhubungan dengan jual beli, sampai balik nama atas nama pembeli.

Pajak jual beli tanah pada dasarnya ada dua yaitu pajak penjual atau pajak penghasilan karena penjualan ( $\mathrm{PPh}$ ) bagi penjual, dan pajak pembeli karena memperoleh hak atas tanah dan bangunan yang disebut dengan Bea Perolehan Hak Atas Tanah dan Bangunan (BPHTB). Pada umumnya masyarakat tidak mengetahui adanya kewajiban membayar pajak peralihan baik BPHTB bagi pembeli maupun PPh bagi penjual, bahkan ada sebagian pihak yang melakukan transaksi jual beli sampai dengan selesainya proses pendaftaran hingga menjadi atas nama pembeli, pihak-pihak tidak mengetahui kalau penjual dan pembeli ada kewajiban 
pembayaran pajak tersebut, sekalipun pajak dimaksud sebenarnya telah dibayar oleh PPAT Notaris atau stafnya, karena umumnya segala pengurusan diserahkan kepada PPAT Notaris. Hal ini sebenarnya yang perlu penyadaran dan pemberian pemahaman kepada masyarakat adanya kewajiban pembayaran pajak baik bagi penjual maupun pembeli.

Ketidaktahuan masyarakat tentang kewajiban pembayaran pajak tersebut, termasuk nilai dasar yang digunakan untuk menghitung pajak termasuk BPHTB maupun tarifnya. Pada umumnya kalaupun sebagian masyarakat mengetahui adanya kewajiban pembayaran pajak tersebut, tetapi mereka tahunya nilai yang digunakan sebagai dasar perhitungan BPHTB adalah Nilai Jual Obyek PajakPajak Bumi dan Bangunan yang tercantum dalam Surat Pemberitahuan Pajak Terutang (NJOP PBB dalam SPPT PBB) tahun yang bersangkutan.

Tabel I

Pengetahuan Responden tentang BPHTB

\begin{tabular}{|l|l|c|c|c|c|}
\hline \multirow{2}{*}{ No. } & \multirow{2}{*}{ Pengetahuan } & \multicolumn{2}{|c|}{ BPHTB } & \multicolumn{2}{c|}{ Cara Menghitung BPHTB } \\
\cline { 3 - 6 } & & Jumlah & $\%$ & Jumlah & $\%$ \\
\hline 1 & Sangat mengetahui & 3 & 10 & 2 & 6,67 \\
2 & Mengetahui & 9 & 30 & 10 & 33,33 \\
3 & Tidak mengetahui & 19 & 60 & 18 & 60,00 \\
\hline & & 30 & 100 & 30 & 100 \\
\hline
\end{tabular}

Sumber Data: Responden masyarakat Kab. Bantul, Kab. Sleman dan Kota Yogyakarta

Berdasarkan data yang diperoleh dari responden masyarakat dalam tabel tersebut, bahwa sebanyak 30 orang responden dari Kabupaten Bantul, Kabupaten Sleman dan Kota Yogyakarta, pengetahuan tentang BPHTB, yaitu sebanyak 3 orang atau $10 \%$ menjawab sangat mengetahui, sebanyak 9 orang atau $30 \%$ menjawab mengetahui, sedang sebanyak 19 orang atau $60 \%$ menjawab tidak mengetahui. Sedangkan pengetahuan tentang menghitung BPHTB dari 30 orang responden, sebanyak 2 orang atau 6,67 \% menjawab sangat mengetahui, sebanyak 10 orang atau 33,33 \% menjawab mengetahui, dan sebanyak 18 orang atau 60,00\% menjawab tidak mengetahui. Dengan demikian tergambar bahwa secara umum masyarakat belum mengetahui adanya kewajiban pembayaran BPHTB termasuk dalam menghitung BPHTB dalam transaksi peralihan hak atas tanah.

Pada dasarnya berkaitan kepatuhan pihak-pihak dalam melaksanakan kewajiban membayar BPHTB sangat patuh, karena bukti pembayaran BPHTB 
dipergunakan sebagai syarat pembuatan-penandatangan akta jual beli dan juga sebagai syarat pendaftaran peralihannya di kantor pertanahan. Di dalam ketentuan undang-undang, ditentukan bahwa Pejabat Pembuat Akta Tanah tidak diperbolehkan menandatangani akta peralihan sebelum diserahkan bukti pembayaran BPHTB berupa Surat Setoran Pajak Daerah (SSPD) yang telah tercantum teraan bukti penerimaan pembayaran dari bank. Hanya saja berkaitan nilai yang dipergunakan sebagai dasar perhitungan pajak BPHTB, tergantung berapa nilai yang nanti akan dikemukakan berdasarkan pengakuan pihak-pihak dihadapan PPAT yang kemudian dituangkan di dalam akta. Pengakuan pihakpihak inilah yang kemungkinan terjadi penggunaan nilai transaksi yang tidak sebenarnya, dan hal ini adalah suatu kewajaran karena pada umumnya pihak mesti keinginannya membayar pajak bisa lebih ringan.

\section{Kepastian Nilai yang Digunakan dalam Perhitungan BPHTB}

Berdsarkan Pasal 87 Undang-Undang Nomor 28 Tahun 2009 tentang Pajak Daerah dan Retribusi Daerah atau UU PDRD, diatur bahwa, dasar pengenaan Bea Perolehan Hak atas Tanah dan Bangunan adalah Nilai Perolehan Objek Pajak. Sedangkan Nilai Perolehan Objek Pajak untuk jual beli adalah harga transaksi. Dengan dasar nilai transaksi ini, maka nilai dasar yang digunakan dalam perhitungan ВРНTВ tergantung dari kesepakatan para pihak dalam melakukan transaksi.Sehingga kepastian kebenaran nilai transaksi yang dianggap telah disetujui dan menjadi dasar perhitungan BPHTB tergantung dari kejujuran para pihak. Tidak menutup kemungkinan nilai transaksi tersebut tidak sesuai dengan yang sebenarnya yang sengaja dilakukan dengan maksud agar pajaknya lebih rendah dari yang sebenarnya.Hal ini tentunya tidak mudah untuk menjamin kapastian bahwa nilai transaksi yang digunakan sebagai dasar perhitungan BРHTB itu adalah nilai transaksi yang sebenarnya ataukah tidak. Hal demikian wajar dapat saja terjadi penurunan harga, mengingat pada umumnya para pihak menghendaki pembayaran pajak yang lebih ringan. Dalam hal ini maka diperlukan adanya validasi untuk melakukan penelitian dan verifikasi secara cermat tentang kebenaran nilai transaksi yang digunakan sebagai dasar perhitungan BPHTB. 
Validasi maksudnya adalah penelitian/verifikasi atas bukti pembayaran yang berupa Surat Setoran Pajak Daerah (SSPD), yang dilakukan oleh petugas dinas yang berwenang, antara lain untuk meneliti kebenaran atas nilai yang digunakan untuk menghitung BРHTB. Berdasarkan ketentuan undang-undang, bahwa yang menjadi dasar perhitungan BPHTB adalah nilai transaksi. Yang menjadi persoalan adalah ketika dihadapan PPAT bisa saja pihak-pihak mengaku bahwa nilai transaksinya tidak sesuai dengan kenyataan, dalam arti lebih rendah dari yang sebenarnya, dengan maksud agar pajak atau BPHTB nya ringan. Dalam hal terjadi demikian, maka pada saat dilakukan validasi ini, ada kemungkinan nilai transaksinya harus dirubah dan disesuaikan dan dengan sendirinya terjadi kurang bayar, karena nilai yang digunakan menghitung ВРНТВ oleh wajib pajak tidak sesuai menurut penilaian petugas yang berwenang meneliti. Disinilah yang dapat menyebabkan kendala dan hambatan dalam proses lebih lanjut pendaftaran peralihan di Kantor Pertanahan, karena harus menunggu proses validasi selesai dengan membayar kekurangannya apabila terdapat kurang bayar. Adanya hambatan dalam proses pendaftaran peralihan hak atas tanah ini tidak sesuai dengan harapan masyarakat, yang umumnya menghendaki proses yang cepat dan sederhana. Hal ini sesuai pernyataan bahwa, merupakan harapan kita semua, bahwa pemrosesan sertifikat setelah persyaratan lengkap dapat diselesaikan dalam jangka waktu yang wajar.Pelayanan aparat pelaksana pendaftaran tanah yang profesional dan transparansi dalam tata kerja serta biaya yang diperlukan, merupakan syarat keberhasilan pelaksanaan pendaftaran tanah. ${ }^{10}$

Berkaitan dengan validasi SSPD ini pada awal pengalihan pengelolaan dari pajak pusat oleh KPP Pratama menjadi pajak darah oleh pemerintah daerah melalui dinas yang berwenang semula menjadi syarat wajib dalam pendaftaran peralihan jual beli di kantor pertanahan, disamping juga validasi atas pajak penjual (PPh) oleh KPP Pratama. Karena terjadi hambatan pada saat pendaftaran peralihan di kantor pertanahan inilah, menimbulkan keluhan masyarakat yang melakukan pengurusan peralihan tanah. Karena untuk syarat pendaftaran harus menunggu validasi SSPD yang kadang memakan waktu yang lama, di samping harus melakukan perubahan

${ }^{10}$ Maria S.W. Sumardjono, Kebijakan Pertanahan Antara Regulasi \& Implementasi, PT. Kompas Media Nusantara, Jakarta, 2002, hlm. 121-122. 
nilai transaksi dan besarnya pembayaran BPHTB ketika nilai yang diajukan wajib pajak tidak sesuai menurut perhitungan dinas yang berwenang. Dengan kondisi demikian, maka dalam perkembangannya kemudian keluar Surat Edaran Kepada Badan Pertanahan Nasional Republik Indonesia nomor : 05 /SE/IV/2003 tentang Pendafataran Hak Atas Tanah atau Pendaftaran Hak atas Tanah terkait dengan pelaksanaan Undang-Undang Nomor 28 Tahun 2009 tentang Pajak Daerah dan Retribusi Daerah, yang ditujukan kepada kepala-kepala kantor pertanahan seluruh Indonesia, yang intinya memerintahkan kantor pertanahan agar menerima pendaftaran peralihan tanah tanpa menunggu validasi bukti pembayaran BPHTB.

Berdasarkan data dan keterangan yang diperoleh ${ }^{11}$ ternyata dalam penerapan kewajiban validasi pembayaran BPHTB pasca Surat Edaran Kepala Badan Pertanahan Nasional nomor 5 /SE/IV/2003 tentang Pendafataran Hak Atas Tanah atau Pendaftaran Hak atas Tanah terkait dengan pelaksanaan Undang-Undang Nomor 28 Tahun 2009 tentang Pajak Daerah dan Retribusi Daerah, berbeda-beda antara wilayah Kabupaten dan Kota yang satu dan lainnya. Bagi kantor pertanahan dalam pendaftaran peralihan hak atas tanah ada yang tidak mensyaratkan validasi, sementara ada yang mengambil jalan tengah tidak mensyaratkan tetapi pada saat mengambil Sertifikat dipersyaratkan adanya bukti pembayaran BPHTB (SSPD) yang sudah divalidasi, juga ada yang tidak mensyaratkan tetapi ada instansi lain dalam proses lain yaitu pada saat validasi pembayaran pajak penjual (PPh) di KPP Pratama yang mensyaratkan validasi BPHTB. Dengan ketidak seragaman dalam pelayanan proses pendaftaran peralihan hak atas tanah terkait dengan persyaratan validasi BPHTB ini tentunya juga dapat menimbulkan ketidakadilan dan tidak adanya kepastian hukum. Untuk itu pada waktu ke depan diharapkan ada perbaikan dan pembenahan melalui kerjasama dan koordinasi yang baik antar instansi dan pihak-pihak yang terkait dengan proses peralihan hak atas tanah dan pembayaran BPHTB, baik Kantor Pertanahan, Dinas pengelola BPHTB, dan PPAT-Notaris.

\footnotetext{
${ }^{11}$ Dari data keterangan yang diperoleh dalam acara Focus Group Discussion (FGD) yang diselenggarakan pada Tanggal 20 Juni 2014 di Kampus Universitas Janabadra, yang dihadiri oleh pejabat BPN dan Dinas pendapatan Kabupaten Bantul, Sleman dan Kota Yogyakarta
} 
Data salah satu narasumber ${ }^{12}$ yaitu Dinas Pengelolaan Pendapatan Keuangan dan Aset Daerah Kabupaten Bantul diperoleh data tentang jumlah obyek pembayaran BPHTB berdasarkan SSPD, baik yang tidak terdapat kurang bayar maupun yang ada kurang bayar. Data ini diambil dalam waktu 3 Tahun terakhir, seperti dalam tabel berikut:

Tabel II

Contoh Data Jumlah Obyek Pembayaran BPHTB/ SSPD

\begin{tabular}{|r|r|r|r|r|r|r|}
\hline No. & Tahun & $\begin{array}{c}\text { BPHTB } \\
\text { Dibayar }\end{array}$ & $\begin{array}{c}\text { BPHTB } \\
\text { Nihil }\end{array}$ & $\begin{array}{c}\text { Validasi Tidak } \\
\text { Kurang Bayar }\end{array}$ & $\begin{array}{c}\text { Validasi } \\
\text { Kurang Bayar }\end{array}$ & Jumlah \\
\hline 01 & 2011 & 3463 & 6326 & - & - & 9789 \\
02 & 2012 & 4950 & 6033 & 10275 & 708 & 21966 \\
03 & 2013 & 5417 & 3461 & 8342 & 536 & 17756 \\
\hline
\end{tabular}

Sumber Data: Isian daftar pertanyaan dari nara sumber Dinas Pengelolaan Pendapatan Keuangan dan Aset Daerah Kabupaten Bantul Tahun 2014

Data tersebut dapat digambarkan bahwa, pada saat validasi masih ditemukan kurang bayar, seperti yang terjadi pada 2012 dari 21.966 BPHTB/SSPD terdapat 708 BPHTB/SSPD kurang bayar atau sebesar : 3,26 \%, sedangkan 2013 dari 17.756 BPHTB/SSPD terdapat 536 BPHTB/SSPD kurang bayar atau 3,01 \%. Dari data tersebut menggambarkan kemungkinan dapat terjadi perbedaan nilai transaksi yang disepakati oleh para pihak dan dituangkan dalam akta, dengan nilai transaksi yang digunakan sebagai dasar perhitungan BPHTB menurut penilaian dinas. Dalam hal inilah terjadi ketidakpastian nilai transaksi mana yang benar, sedangkan kalau terjadi ketidaksesuaian nilai transaksi yang sebenarnya, maka kalau terjadi sengketa dapat mengakibatkan aktanya menjadi batal. Dari hasil validasi memang ada kemungkinan benar-benar terdapat kekurangan bayar, tetapi ada kemungkinan dari kurang bayar tersebut wajib pajak harus membayar lebih dari yang seharusnya. Sehingga ada kemungkinan dapat merugikan wajib pajak, karena harus membayar pajak lebih besar dari yang sebenarnya.

Dari data dan keterangan yang diperoleh bahwa antara nilai transaksi dengan NJOP PBB terdapat selisih yang beragam, tetapi secara umum nilai transaksi lebih tinggi dari NJOP PBB. NJOP PBB ini tercantum dalam Surat Pemberitahuan Pajak Terutang Pajak Bumi dan Bangunan (SPPT PBB) yang

${ }^{12}$ Dari keterangan yang diperoleh dari wawancara dengan bapak Anggit Nur Hidayat, S.H, M.AP Ka. Sie pengendalian opsl. pemeriksaan dan penindakan pada kantor DPPKAD Kabupaten Bantul, pada tanggal 06 Mei 2014 dan dalam isian daftar pertanyaan dalam bentuk tabel. 
dikeluarkan oleh dinas dan disampaikan kepada wajib pajak PBB setiap tahun pada pajak tahun berjalan. NJOP PBB yang tercantum dalam SPPT PBB ini memuat nilai jual tanah dan bangunan yang secara periodik ditinjau dengan memperhatikan dan menyesuaikan perkembangan nilai tanah dan bangunan pada wilayah letak tanah yang bersangkutan.

Di samping itu, dari data keterangan narasumber dari Kantor Pertanahan baik di Kota Yogyakarta, Kabupaten Bantul dan kabupaten Sleman, ${ }^{13}$ telah dibuat Zona Nilai Tanah (ZNT) yang secara umum besarnya di atas NJOP PBB bahkan hampir mendekati nilai pasar. ZNT ini dipergunakan sebagai dasar menghitung berapa besar Penerimaan Negara Bukan Pajak (PNBP) untuk pendaftaran peralihan hak atas tanah. ZNT ini selalu ditinjau secara periodik dengan memperhatikan dan menyesuaikan perkembangan nilai tanah pada wilayah tanah yang bersangkutan.

Dengan demikian sebenarnya ada beberapa alternatif nilai yang ditetapkan oleh instansi yang berwenang selain nilai transaksi, yaitu NJOP PBB yang tercantum dalam SPPT PBB yang dikeluarkan oleh dinas pendapatan Kabupaten/Kota, dan ZNT yang dikeluarkan oleh Kantor Pertanahan sebagai dasar pengenaan Penerimaan Negara Bukan Pajak (PNBP) dalam pendaftaran peralihan tanah. Beberapa nilai yang sudah ditetapkan tersebut dapat digunakan sebagai alternatif ataupun dikombinasikan, untuk pertimbangan dalam menentukan nilai mana sebaiknya yang digunakan sebagai dasar perhitungan BPHTB. Penggunaan nilai dimaksud diharapkan dapat memberikan kepastian dan rasa keadilan bagi masyarakat, terlebih juga mempermudah prosedur bagi wajib pajak dalam memenuhi kewajiban pembayaran BPHTB.

Berdasarkan data hasil penelitian yang diperoleh dari responden menggambarkan bahwa pada umumnya responden masyarakat belum mengetahui dan memahami adanya kewajiban pembayaran pajak pembeli yang disebut BPHTB, di samping itu perhitungan maupun pembayaran biasanya tidak dilakukan sendiri tetapi diserahkan kepada pihak lain seperti PPAT-Notaris atau melalui stafnya. Sehingga wajib pajak atau pembeli tidak mengetahui bagaimana cara menghitungnya, termasuk pembayarannya.

\footnotetext{
${ }^{13}$ Dari data keterangan yang diperoleh dalam acara Focus Group Discussion (FGD) yang diselenggarakan pada 20 Juni 2014 di Kampus Universitas Janabadra, yang dihadiri oleh pejabat BPN dan Dinas Pendapatan Kabupaten Bantul, Sleman dan Kota Yogyakarta
} 
Tabel III

Penghitungan dan Pengurusan Pembayaran BPHTB

\begin{tabular}{|l|l|r|r|}
\hline No. & \multicolumn{1}{|c|}{ Yang Melaksanakan } & Jumlah & \multicolumn{1}{|c|}{$\%$} \\
\hline 1 & Dihitung dan dibayar Wajib Pajak sendiri & 6 & 20 \\
2 & Diserahkan Kepada PPAT & 17 & 56,67 \\
3 & Tidak Tahu & 7 & 23,33 \\
\hline & Jumlah & 30 & 100 \\
\hline
\end{tabular}

Sumber data : Responden masyarakat Kab. Bantul, Kab. Sleman dan Kota Yogyakarta

Berdasarkan data yang diperoleh dari responden masyarakat dari Kabupaten Bantul, Kabupaten Sleman dan Kota Yogyakarta, dalam tabel tersebut, menggambarkan bahwa pada umumnya pengurusan penghitungan dan pembayaran BPHTB tidak dilakukan sendiri, tetapi diserahkan kepada pihak lain yaitu PPAT. Dari sejumlah 30 orang responden berpendapat sejumlah 6 orang atau $20 \%$ menghitung dan membayar sendiri, sejumlah 17 orang atau 56,67\% penghitungan dan pembayarannya diserahkan kepada PPAT, sedang 7 orang atau 23,33 \% menjawab tidak tahu. Jumlah yang terakhir dengan jawaban tidak tahu ini ada kemungkinan penghitungan dan pembayarannya juga sudah dilakukan oleh pihak lain, sehingga menjawab tidak tahu.

Berkaitan dengan nilai yang digunakan sebagai dasar perhitungan BPHTB, secara umum responden masyarakat tahunya perhitungan BPHTB itu dihitung dari nilai NJOP PBB yang tercantum dalam SPPT PBB. Di samping itu masyarakat menghendaki adanya kepastian nilai yang digunakan sebagai dasar perhitungan BPHTB, sehingga mempermudah dan memberikan kepastian wajib pajak dalam menghitung berapa BPHTB yang harus dibayar sejak awal.

Tabel IV

Pendapat Responden tentang Nilai yang Digunakan Dasar Perhitungan BPHTB

\begin{tabular}{|c|c|c|c|}
\hline No. & Pendapat/ Usulan & Jumlah & $\%$ \\
\hline 1 & NJOP yang tercantum dlm SPPT PBB & 17 & 56,67 \\
\hline 2 & Nilai Transaksi & 4 & 13,33 \\
\hline 3 & Nilai Standar yang ditentukan & 2 & 6,67 \\
\hline 4 & Tidak tahu & 7 & 23,33 \\
\hline & Jumlah & 30 & 100 \\
\hline
\end{tabular}

Sumber Data: Responden masyarakat Kab. Bantul, Kab. Sleman dan Kota Yogyakarta 
Berdasarkan data yang diperoleh dari responden masyarakat dari Kabupaten Bantul, Kabupaten Sleman dan Kota Yogyakarta, dalam tabel tersebut, bahwa sebanyak 30 responden, yang berpendapat nilai yang digunakan sebagai dasar perhitungan BPHTB adalah NJOP yang tercantum dalam SPPT PBB sebanyak 17 orang atau $56,67 \%$, yang berpendapat nilai yang digunakan sebagai dasar perhitungan BPHTB adalah nilai transaksi sebanyak 4 orang atau 13,33\%, yang berpendapat nilai yang digunakan sebagai dasar perhitungan BPHTB adalah nilai standar yang ditentukan sebanyak 2 orang atau $6,67 \%$, dan yang menjawab tidak tahu sebanyak 7 orang atau $23,33 \%$. Dengan demikian tergambar bahwa secara umum masyarakat menghendaki adanya kepastian nilai yang digunakan sebagai dasar perhitungan BPHTB seperti nilai NJOP yang tercantum dalam NJOP PBB.

Demikian pula data dan keterangan yang diperoleh dari para PPATNotaris, ${ }^{14}$ pada umumnya mengeluhkan adanya ketidakpastian berasnya nilai BPHTB yang harus dibayar, sehubungan nilai transaksi yang digunakan sebagai dasar menghitung BPHTB antara yang disepakati oleh pihak-pihak dengan dinas sering terjadi perbedaan, dan tidak jarang harus diadakan perubahan nilai transaksi sesuai penilaian dinas dan harus menambah BPHTB yang harus dibayar. Yang menjadi persoalan adalah ketika akta jual beli sudah resmi ditandatangani dengan nilai transaksi sesuai dengan kesepakatan antara penjual dan pembeli, di waktu kemudian pada saat diajukan validasi terdapat berbedaan nilai transaksi menurut perhitungan dinas dan harus diadakan perubahan. Dalam hal ini mana nilai transaksi yang sebenarnya, apakah nilai yang telah disepakati pihak-pihak dan dimuat di dalam akta yang sudah ditandatangani, atau nilai yang harus diikuti menurut perhitungan dinas. Sedangkan penggunaan nilai dalam akta yang tidak sesuai dengan kenyataan yang sebenarnya ada konsekuensi yuridis, sehingga apabila terjadi sengketa dapat menjadi batal.

Sedangkan keterangan dan pendapat yang diperoleh dari narasumber dari dinas pendapatan Kabupaten/Kota yang berwenang mengelola BPHTB menghendaki bahwa nilai yang dipergunakan sebagai dasar perhitungan BPHTB tetap menggunakan dasar nilai transaksi, dengan pertimbangan bahwa nilai 
tanah selalu mengalami perkembangan terutama kenaikan, sehingga tidak dapat ditentukan secara tetap. Oleh karena itu juga menghendaki tetap adanya kewajiban validasi pada setiap pembayaran BPHTB untuk meneliti kesesuaian obyek pajak dan nilai transaksi yang sebenarnya.

Sedangkan keterangan dan pendapat yang diperoleh dari narasumber Kantor Pertanahan, ${ }^{15}$ bahwa prinsipnya berpegang pada Surat dari Kepala Badan Pertanahan Nasional Nomor : 5 /SE/IV/2003 tentang Pendafataran Hak Atas Tanah atau Pendaftaran Hak atas Tanah terkait dengan pelaksanaan UndangUndang Nomor 28 Tahun 2009 tentang Pajak Daerah dan Retribusi Daerah, diperoleh pendapat dan keterangan berkaitan dengan kewajiban validasi, yaitu bahwa kewajiban validasi atas pembayaran ВРНTB berbeda-beda antara wilayah Kabupaten dan Kota. Bagi kantor pertanahan dalam pendaftaran peralihan hak atas tanah ada yang tidak mensyaratkan validasi, sementara ada yang mengambil jalan tengah tidak mensyaratkan tetapi pada saat mengambil Sertifikat dipersyaratkan adanya bukti pembayaran BPHTB (SSPD) yang sudah divalidasi, juga ada yang tidak mensyaratkan tetapi ada instansi lain yaitu pada saat validasi pembayaran pajak penjual (PPh) di KPP Pratama mensyaratkan validasi BPHTB.

Berdasarkan uraian dari data dan keterangan yang diperoleh dari penelitian tersebut, terdapat permasalahan terutama yang berhubungan dengan penggunaan nilai transaksi dalam perhitungan BPHTB, yang berakibat ketidakpastian nilai transaksi mana yang digunakan manakala terjadi perbedaan antara kesepakatan para pihak dengan penafsiran dinas pengelola, demikian pula menyangkut berapa BPHTB yang harus di bayar dengan adanya kemungkinan terjadi kurang bayar menurut penilaian dinas pengelola, termasuk berakibat menghambat proses pendaftaran peralihan hak atas tanah lebih lanjut.

Untuk itu dalam rangka menjamin kepastian dalam pembayaran BPHTB, perlu adanya ketetapan nilai harga tanah secara standar yang ditetapkan oleh instansi yang berwenang, seperti halnya dalam pengenaan pajak bumi dan bangunan, dibuat Nilai Jual Obyek Pajak (NJOP) yang dikeluarkan setiap tahun pajak oleh instansi yang berwenang sebagai dasar menghitung pajak PBB. NJOP

${ }^{15}$ Dari data keterangan yang diperoleh dalam acara Focus Group Discussion (FGD) yang diselenggarakan pada Tanggal 20 Juni 2014 di Kampus Universitas Janabadra, yang dihadiri oleh pejabat BPN dan Dinas pendapatan Kabupaten Bantul, Sleman dan Kota Yogyakarta. 
PBB tersebut dimuat dalam Surat Pemberitahuan Pajak Terutang Pajak Bumi dan bangunan (SPPT PBB) dan disampaikan kepada wajib pajak setiap tahun dan ditinjau secara periodik dengan menyesuaikan perkembangan harga tanah di wilayah yang bersangkutan.

Dalam menetapkan nilai harga yang akan digunakan sebagai dasar perhitungan BPHTB, dapat dilakukan dengan berkoordinasi antar instansi yang berhubungan, antara lain antara dinas pendapatan pemerintah Kabupaten/ Kota dengan Kantor Pertanahan. Dalam hal ini dinas pendapatan pemerintah Kabupaten/ Kota mempunyai ketetapan nilai yang dibuat dan digunakan untuk menghitung PBB yaitu dengan Nilai Jual Obyek Pajak Bumi dan Bangunan (NJOP PBB), sedang Kantor Pertanahan mempunyai ketetapan nilai yang dibuat dan digunakan untuk menghitung Penerimaan Negara Bukan Pajak (PNBP) setiap pendaftaran tanah yang disebut Zona Nilai Tanah (ZNT), dengan mengkombinasikan antar nilai tersebut yang paling sesuai sebagai dasar perhitungan BPHTB. Sedangkan untuk nilai transaksi atas bangunan dapat didasarkan pada nilai NJOP bangunan yang terdapat pada SPPT PBB yang bersangkutan atau diadakan perhitungan dan penilaian tersendiri.Namun yang menjadi persoalan adalah payung hukum yang menjadi dasar penentuan nilai tersebut. Sehingga sebagai landasan hukum dalam menentukan nilai harga yang dapat ditetapkan oleh masing-masing pemerintah daerah perlu diadakan perubahan Undang-Undang, yaitu Undang-Undang 28 Tahun 2009 tentang Pajak Daerah dan Retribusi Daerah khususnya Pasal 87 yang mengatur bahwa, dasar pengenaan Bea Perolehan Hak atas Tanah dan Bangunan adalah Nilai Perolehan Objek Pajak. Sedangkan Nilai Perolehan Objek Pajak untuk jual beli adalah harga transaksi.Ketentuan yang menyelaskan bahwa nilai perolehan obyek pajak adalah nilai transaksi inilah yang perlu diadakan perubahan.

Usulan perubahan pasal tersebut yaitu menjadi sebagai berikut : ... bahwa yang dimaksud "Nilai Perolehan Obyek Pajak" adalah nilai yang ditetapkan oleh pemerintah daerah Kabupaten/ kota melalui instansi yang diberi kewenangan untuk itu, dengan ketentuan apabila belum ditetapkan nilai oleh instansi dimaksud, maka nilai perolehan obyek pajak, dengan menggunakan Nilai Obyek Pajak pada Pajak Bumi dan Bangunan (NJOP PBB) yang tercantum pada Surat 
Pemberitahuan Pajak Terutang Pajak Bumi dan Bangunan (SPPT PBB) pada tahun yang bersangkutan.

Dasar pertimbangan usulan perubahan tersebut, agar terjamin adanya kepastian nilai yang dipergunakan untuk menghitung BРНTB dan dengan sendirinya juga berapa BPHTB yang harus dibayar oleh wajib pajak.Sehingga dari sejak awal wajib pajak dengan mudah dan dapat memastikan berapa BPHTB yang harus dibayar. Dengan adanya perhitungan yang sudah pasti tersebut, maka akan mempermudah dan memberi kepastian wajib pajak dalam membayar BPHTB dan tidak diperlukan lagi validasi yang harus melalui prosedur yang rumit dan memakan waktu, dan dengan sendirinya akan mempermudah dan mempercepat proses pendaftaran tanah lebih lanjut pada Kantor Pertanahan yang berwenang. Sesuai tujuan utama reformasi perpajakan menurut Chaizi Nasucha, adalah untuk mencapai efektifitas yang tinggi, yaitu kemampuan untuk membuat biaya administrasi penerimaan pajak sekecil-kecilnya. ${ }^{16}$

\section{Penutup}

Penelitian ini menyimpulkan sebagai berikut: Pertama, penggunaan nilai transaksi sebagai dasar perhitungan BPHTB menimbulkan ketidakpastian, baik nilai transaksinya yang bisa berubah, perhitungan maupun jumlah pajak yang harus dibayar oleh wajib pajak, setelah hasil validasi yang dilakukan oleh dinas pengelola BPHTB, disamping keharusan validasi melalui proses yang memakan waktu dan berakibat menghambat proses pendaftaran peralihan hak atas tanah. Kedua, agar ada kepastian dalam pembayaran BPHTB, maka perlu ditentukan nilai yang pasti sebagai dasar perhitungan BРНTB oleh instansi yang berwenang, misalnya dengan menggunakan Nilai Jual Obyek Pajak pada Pajak Bumi dan Bangunan (NJOP PBB) yang tercantum dalam Surat Pemberitahuan Pajak Terutang Pajak Bumi dan Bangunan (SPPT PBB), atau nilai yang ditetapkan oleh instansi yang berwenang. 


\section{Daftar Pustaka}

Ariyanti, Sri, "Pemungutan Bea Perolehan Hak Atas Tanah Dan Bangunan (BPHTB) Dalam Jual Beli Tanah Dan Atau Bangunan Di Kota Semarang", Undip, Semarang, 2006.

Al Rashid, Harun, Sekilas Tentang Jual Beli Tanah (Berikut Peraturan-peraturannya), Ghalia Indonesia, Jakarta, 1987.

Adrian Sutedi, Hukum Pajak dan Retribusi Daerah, Ghalia Indonesia, Bogor, 2008.

Bambang Waluyo, Penelitian Hukum Dalam Praktek, Sinar Grafika, Jakarta, 1991.

Harsono, Budi, Hukum Agraria Indonesia, Djambatan, Jakarta, 2007.

Murtir Jeddawi, Implementasi Kebijakan Otonomi Daerah (Analisis Kewenangan, Kelembagaan, managemen Kepegawaian, dan Peraturan Daerah), Total Media, Yogyakarta, 2008.

Pudiatmoko, Sri Y., Pengantar Hukum Pajak, Penerbit Andi offset, Yogyakarta, 2002.

Sumardjono Maria S.W, Kebijakan Pertanahan Antara Regulasi E Implementasi, PT. Kompas Media Nusantara, Jakarta, 2002.

Suroso, Ismuhadi, Pendaftaran Tanah Di Indonesia, PT Relindo Jayatama, Jakarta, 1999.

Suratman, dan Philips Dillah, Metode Penelitian Hukum, Alfabeta, Bandung, 2012.

Widhyarsi, Dyah Purworini "Pelaksanaan Pemungutan Bea Perolehan Hak Atas Tanah Dan Bangunan (BPHTB) Atas Hibah Wasiat Di Jakarta Barat", Universitas Diponegoro, Semarang, 2008.

Wahjono, Padmo, Undang-undang Perpajakan Beserta Penjelasan dan Peraturan Pelaksanaan, Ghalia Indonesia, Jakarta, 1984.

Undang-Undang Republik Indonesia Nomor 21 Tahun 1997 Tentang Bea Perolehan Hak Atas Tanah Dan Bangunan (Lembaran Negara Republik Indonesia Tahun 1997 Nomor 3688)

Undang-Undang Republik Indonesia Nomor 20 Tahun 2000 tentang Perubahan Atas Undang-Undang Nomor 21 Tahun 1997 Tentang Bea Perolehan Hak Atas Tanah Dan bangunan (Tambahan Lembaran negara Republik Indonesia Nomor 9)

Undang-Undang Republik Indonesia Nomor 28 Tahun 2009 tentang Pajak Daerah dan Retribusi Daerah (Tambahan Lembaran Negara Republik Indonesia Nomor 5049) 